University of Rhode Island

DigitalCommons@URI

Open Access Master's Theses

1967

\title{
Ultransonic Degradation of Aspirin in Mixed Solvent Systems
}

Thomas E. Needham

University of Rhode Island

Follow this and additional works at: https://digitalcommons.uri.edu/theses

\section{Recommended Citation}

Needham, Thomas E., "Ultransonic Degradation of Aspirin in Mixed Solvent Systems" (1967). Open Access Master's Theses. Paper 211.

https://digitalcommons.uri.edu/theses/211

This Thesis is brought to you for free and open access by DigitalCommons@URI. It has been accepted for inclusion in Open Access Master's Theses by an authorized administrator of DigitalCommons@URI. For more information, please contact digitalcommons-group@uri.edu. 


\title{
ULTRASONIC DEGRADATION OF ASPIRIN
}

IN

MIXED SOLVENT SYSTEMS

BY

THOMAS E. NEEDHAM, JR.

\begin{abstract}
A THESIS SUBMITTED IN PARTIAL FU LFILLMENT OF THE
REQUIREMENTS FOR THE DEGREE OF

MASTER OF SCIENCE

IN
\end{abstract}

PHARMACEUTICAL SCIENCES

UNIVERSITY OF RHODE ISLAND 


\section{MASTER OF SCIENCE THESIS \\ OF \\ THOMAS E. NEEDHAM, JR.}

\section{Approved:}

Thesis Committee:

Chairman

Dean of the Graduate School

UNIVERSITY OF RHODE ISLAND

1967

ii 


\section{ABSTRACT}

The effect of ultrasonic energy on the degradation of aspirin in ethanol-water, diethylether-water, and diethylene glycol-water solvent systems has been studied. The concentration ratios of each solvent system was varied and examined at several different temperatures. Aliquots were withdrawn simultaneously from the control and ultrasonified systems, and analyzed spectrophotometrically. It was found that the application of ultrasound to a system undergoing degradation would cause an increase in the rate but the same kinetic order was maintained. The heat of activation was lowered by the mechanical vibrations of the ultrasonic energy. It is postulated that the ultrasonic vibration increases the effect of the movement of molecules toward each other and the movement of the products away from each other on the overall rate of reaction. As the concentration ratio was increased in the diethylene glycolwater system, the subsequent increase in viscosity reduced the effect that ultrasonic vibration had on the movement of molecules. 
TITLE ABSTRACT

ULTRASONIC DEGRADATION OF ASPIRIN 
TABLE OF CONTENTS

PAGE

ABSTRACT . . . . . . . . . . . . iii

TABLE OF CONTENTS............ .11

LIST OF TABLES . . . . . . . . . . . . 2

LIST OF FIGURES . . . . . . . . . . . . . 3

I. INTRODUCTION . . . . . . . . . . 4

II. EXPERIMENTAL . . . . . . . . . 6

III. RESULTS AND DISCUSSION . . . . . . . 10

IV. CONCLUSIONS . . . . . . . . . 24

V. REFERENCES . . . . . . . . . 25 


\section{LIST OF FIGURES}

FIGURE

PAGE

1. Beer's Law for Salicylic Acid in Ethanol . .

2. Beer's Law for Salicylic Acid in Diethyl Ether .

3. Beer's Law for Salicylic Acid in Diethylene

Glycol . . . . . . . . . . . .

4. Pseudo First Order Degradation of Aspirin in $10 \%$ Ethanol at $20^{\circ} \mathrm{C}$. Exposed to Ultrasound

5. Pseudo First Order Degradation of Aspirin in $1 \%$ Diethyl Ether at $20^{\circ} \mathrm{C}$. Exposed to Ultra. sound

6. Pseudo First Order Degradation of Aspirin in 5\% Diethylene Glycol at 200C. Exposed to Ultrasound . . . . . . . . . . . .

7. Comparison of the Rate of Degradation of Aspirin in Diethylene Glycol with Viscosity at $20^{\circ}, 30^{\circ}$, $40^{\circ} \mathrm{C}$. . . . . . . . . . . . 


\section{INTRODUCTION}

Ultrasound energy at frequencies of $20 \mathrm{KC}$ or above has been used to affect the rate and yield of a number of chemical reactions. Polymerization reactions (1-3), esterification reactions (4), oxidative reactions (5), and reactions involving saponification (6) have all been found to be influenced by ultrasound. Several hydrolysis reactions can be accelerated by an ultrasonic field including the degradation of Procaine (7), Ethyl Acetate (8), and aspirin (9).

Several studies on the hydrolysis of aspirin have been reported in the literature. Edwards, in a series of papers $(10,11)$ reported studies of the mechanism of aspirin degradation in aqueous systems in the absence of ultrasound and found that the overall rate of aspirin hydrolysis followed a pseudo-first order rate which was an average of six distinct $\mathbf{k}$ values.

Garrett studied the effect of mixing alcohol and dioxane in varying concentrations with water on the hydrolysis of aspirin in the absence of ultrasound $(12,13)$. He reported that as ethanol concentration was increased, the rate of hydrolysis also increased. Further, he postulated and established a mechanism which showed that ethyl acetate was formed in the presence of ethanol and that this speeded up 
the hydrolysis reaction. He found, however, that the addition of dioxane had little or no effect on the rate of hydrolysis, and that there was no significant difference from the rate observed in the aqueous system.

One study of the hydrolysis of aspirin in an aqueous system was reported by Mario and Gerraughty (14). They studied the influence of ultrasound on the degradation of aspirin at several temperatures and various hydrogen ion concentrations. They found that ultrasound increased the hydrolysis rate in all cases, but that the kinetic order of the reaction was unchanged.

It was decided that it would be worthwhile to study the influence of ultrasound on the degradation of aspirin dissolved in mixtures of water and other solvents in varying concentrations. It also appeared desirable to study each of the systems selected at three different temperatures to be able to calculate an energy of activation $\left(\mathrm{E}_{\mathrm{a}}\right)$ for each system. One half of each solution would be kept under normal conditions and studied kinetically at the same time intervals as the portion of the solution which was exposed to ultrasonic energy.

It was decided to conduct this investigation using the same generator used by Mario and Gerraughty (15), in order to have a better basis for comparison of results. The frequency, $100 \mathrm{KC}$, produced by this piezzoelectric generator appeared to be ideal, since higher frequencies produce too many drastic side effects, and lower frequencies may not produce significant energy to influence the reaction. 


\section{EXPERIMENTAL}

General Procedure - A similar process was devised for the alcoholwater, ether-water, and ethylene glycol-water systems and variations from this general procedure are discussed separately.

A stock solution containing $100 \mathrm{mg}$. of aspirin in $100 \mathrm{ml}$. of water was prepared. Duplicate samples were made for each run and contained $5 \times 10^{-4}$ moles of the freshly prepared aspirin from the stock solution; the proper amount of each solvent to give the required percentage; and $5 \mathrm{ml}$. of concentrated sodium acetate-acetic acid buffer solution which, when brought to a volume of $50 \mathrm{ml}$. with distilled water, gave a buffer capacity of 0.01 and a $\mathrm{pH}$ of 3.67 .

One sample was placed in the water bath and the other in the ultrasonic bath and allowed to equilibrate to the constant temperature selected. An aliquot of sample was withdrawn, and the ultrasonic generator started. This first portion showed the exact amount of a spirin present at the beginning of each study and made it unnecessary to insure the purity of aspirin at time zero. All aliquots were removed simultaneously from the ultrasonic and control vessels, and the absorbance was determined on a Beckman DU spectrophoto- 
meter(1) with the absorbances and time recorded.

As seen in previous papers $(10-15)$, an accurate method to analyze aspirin degradation was through spectrophotometric determination of the salicylic acid produced. Using a recording spectrophotometer (2), the optimum wave length for determination of salicylic acid was found to be at $298 \mathrm{mu}$ as the other substances in the solution did not absorb at this wavelength. Beer's law plots of absorbance vs. molar concentration of salicylic acid were prepared for each solvent used.

Ethyl Alcohol - Alcohol, U.S. P. was diluted to give concentrations of $10 \%, 30 \%, 50 \%$ and $70 \%(W / V)$. The same buffer capacity of 0.01 was used for all concentrations of alcohol, however, with increasing percentages of alcohol, the apparent pH showed a gradual increase. Kinetic studies were made $20^{\circ}, 30^{\circ}$, and $40^{\circ} \mathrm{C}$. at each concentration of alcohol so the Arrhenius equation could be used to determine the activation energies for each concentration.

Eiethyl ether - Since the solubility of the diethyl ether in water was limited, it was decided that $1 \%, 3 \%$ and $5 \%$ concentrations would give evidence of the effect of ether on aspirin degradation. The tempera-

(1) Beckman DU Spectrophotometer with automatic power supply, Beckman Instruments Inc., 2500 Harbour Blvd., Fullerton, Cal.

(2) Bausch Lomb 505 Spectrophotometer, Rochester, N. Y. 
ture at which the runs were made also had to be varied. Since diethyl ether has a boiling point of $34.5^{\circ} \mathrm{C}$. , the runs were made at $20^{\circ}$, $30^{\circ}$, and $40^{\circ} \mathrm{C}$. to obtain the values necessary to determine the activation energy. As a precaution, the necks of the reaction flasks were insulated and condensers attached to each flask to prevent vaporization of the ether.

Ethylene Glycol - Ethylene Glycol is miscible with water, so a wider variation of percentage concentrations could be used. Studies were made at $5 \%, 10 \%, 30 \%$ and $50 \%(\mathrm{~V} / \mathrm{V})$ concentrations. The temperatures used were $20^{\circ}, 30^{\circ}$, and $40^{\circ} \mathrm{C}$. Viscosities of each solution were determined, also, to see if this physical property affected the degradation rate.

Equipment:

The ultrasonic energy at a frequency of 100 K. C. was supplied by a McKenna ultrasonic generator ${ }^{(1)}$. This instrument is powered by an electrical oscillator with variant frequency control. The generated electrical energy is changed to ultrasonic energy by means of a transducer. This apparatus uses a Barium titinate transducer mounted at the bottom of a water bath. When a voltage is applied across this crystal a realignment of the inner charges causes a slight change in size. The crystal vibrating at the frequency of the

(1) Model 100 Generator, McKenna Labs. , 2503 Main Street, Santa Monica, California 
voltage from the oscillator will change generated electrical current to mechanical ultrasonic vibrations. The transducer, itself, is so mounted as to radiate the ultrasonic waves through a water bath. To maintain constant temperature throughout the system, a coiled copper tubing was inserted into the bath and connected to a constant temperature water bath. (1) By adjustment of this water bath, the temperature of the system could be varied to the desired level and held constant to within $\pm 0.25^{\circ} \mathrm{C}$. throughout each study.

(1) Model 3052 Labine Instruments Inc., Chicago, Illinois 


\section{RESULTS AND DISCUSSION}

Figures 1 through 3 illustrate typically how salicylic acid followed a Beer's Law relationship for all variations of the three solvent mediums: ethyl alcohol, diethyl ether, and diethylene glycol. As the concentration ratio of the solvents was varied the slope of the line in each of these systems was close enough to being the same to be considered to be equal within experimental error.

Samples under the influence of ultrasound followed a pseudo-first order degradation as shown in Figures 4 through 6 which show representative plots for each of the three solvent systems. The complete results for each system is listed in Tables I through III. In each solvent the rate was increased when the degradation was carried out under simultaneous exposure to ultrasound. The subsequent heat of activation as calculated from the Arrhenius equation is also included for each solvent system. The lower heat of activation required for those systems subjected to ultrasound would indicate that the mechanical vibrations caused by the ultrasonic energy contributed to the energy required by the system to effect degradation. Since the thermal energy was kept constant for both the untrasonified and control systems, the additional ultrasonic energy increased the kinetic rates. 


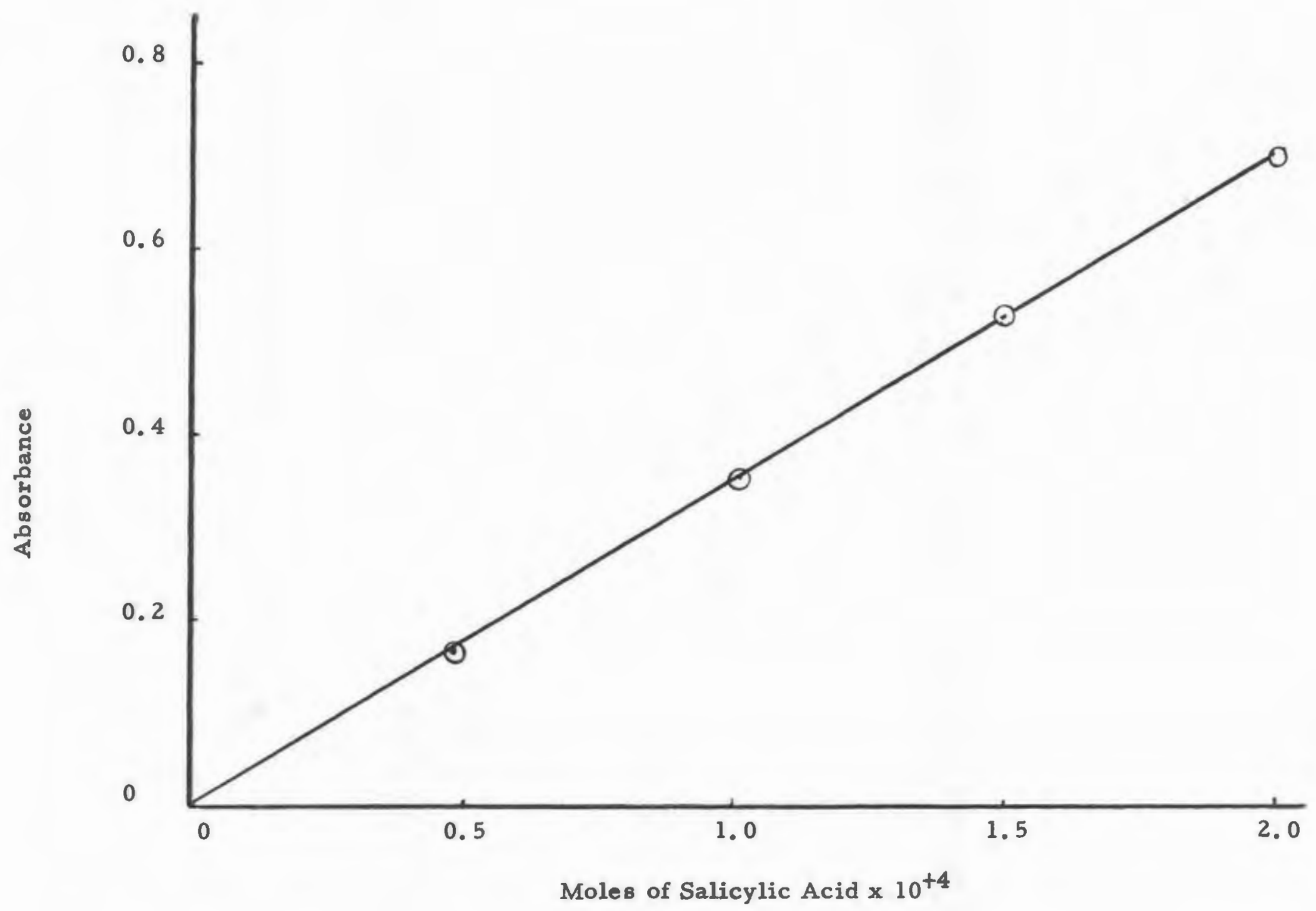

Figure 1. Beer's Law Plot of Salicylic Acid in 10\% Ethyl Alcohol 


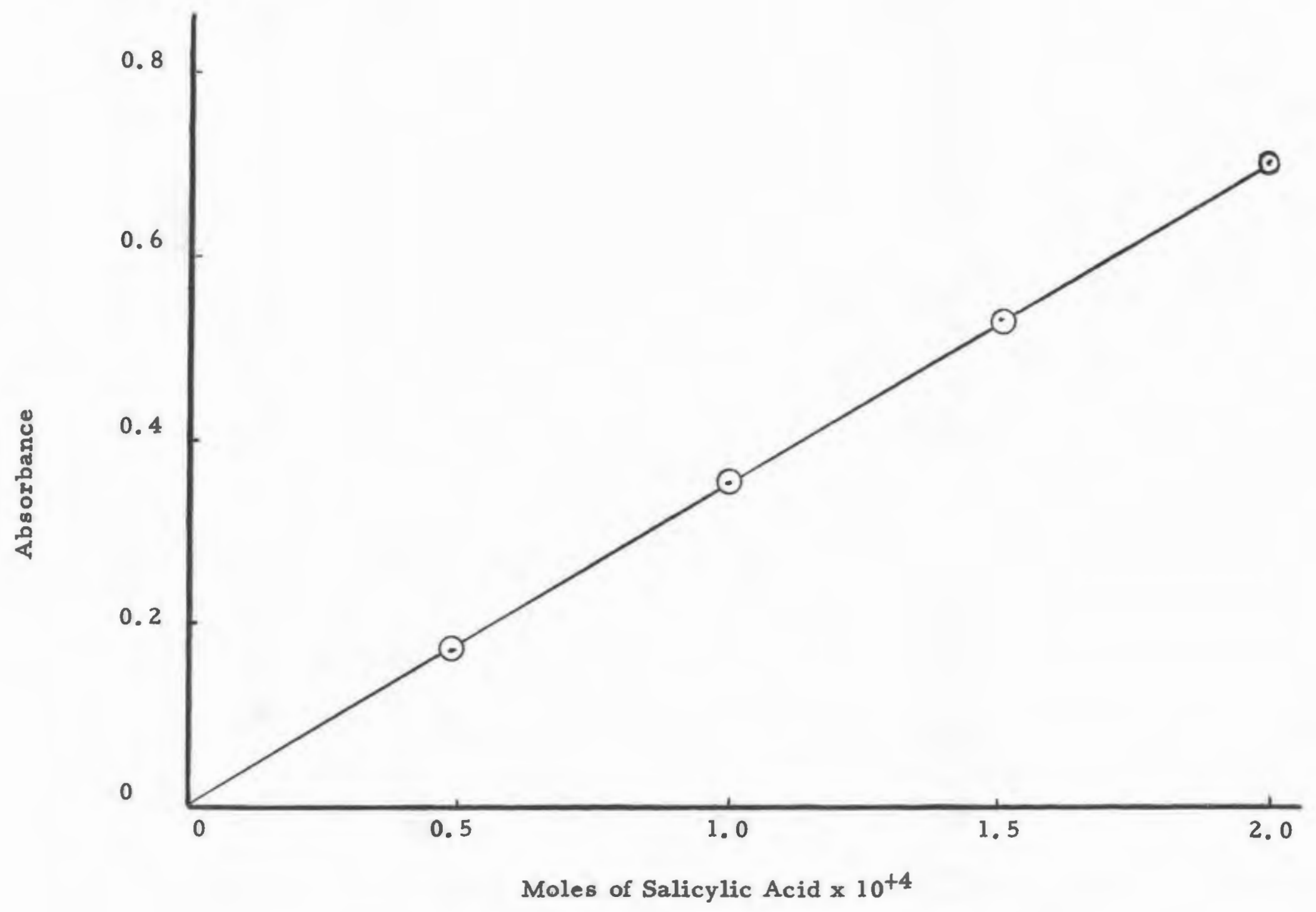

Figure 2. Beer's Law Plot of Salicylic Acid in 3\% Diethyl Ether at $298 \mathrm{m \mu}$. 


$$
L=
$$




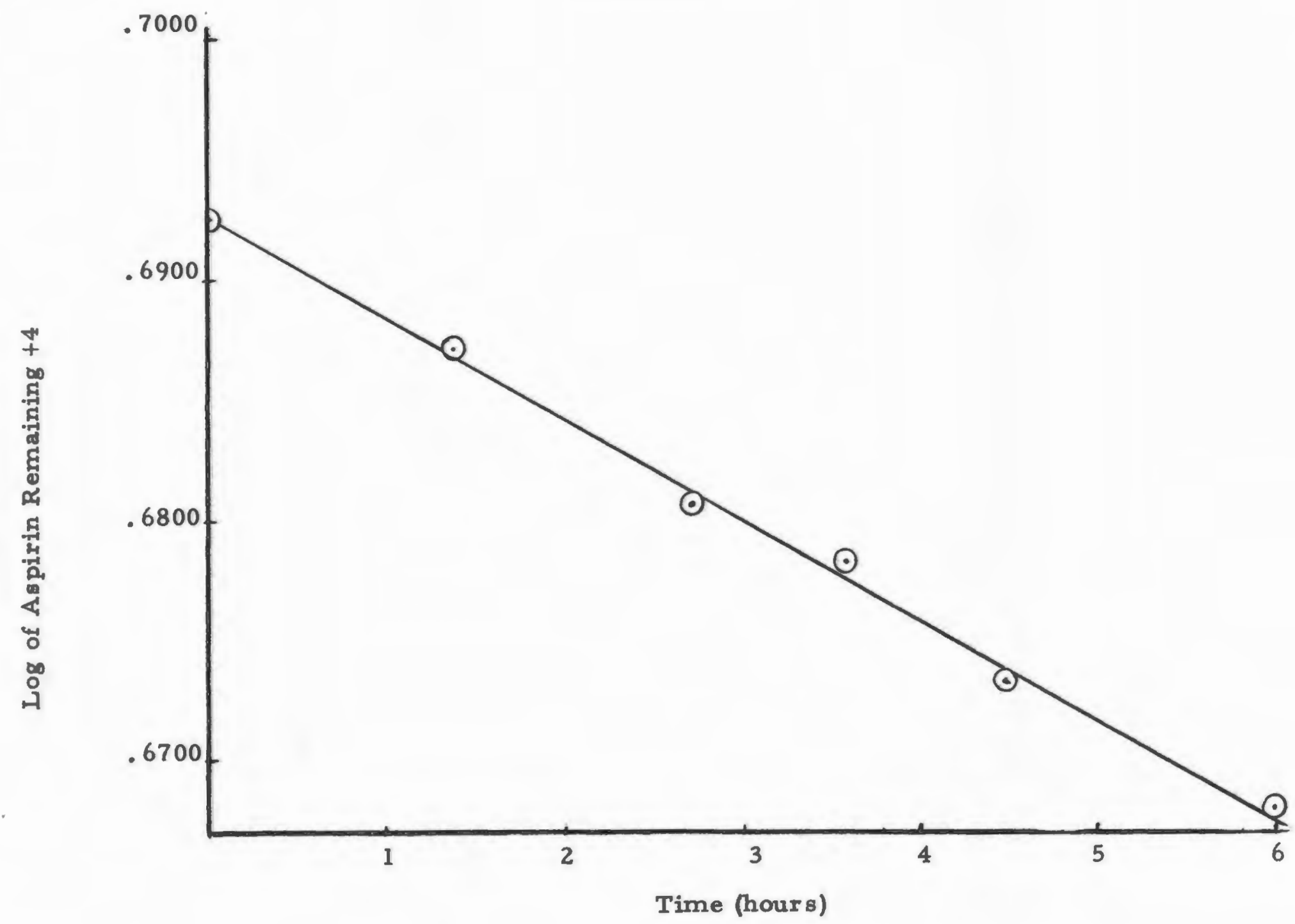

Figure 4. Pseudo First Order Degradation of Aspirin in 10\% Ethanol at $20^{\circ} \mathrm{C}$. Exposed to Ultrasound. 
TABLE I

THE EFFECT OF ULTRASONIC ENERGY ON THE

DEGRADATION OF ASPIRIN IN SOLUTIONS

OF ETHANOL

\begin{tabular}{|c|c|c|c|c|c|}
\hline $\begin{array}{l}\quad \quad \text { (a) } \\
\text { Percent } \\
\text { Ethyl } \\
\text { Alcohol }\end{array}$ & $\begin{array}{l}\text { Temper- } \\
\text { ature } \\
{ }^{\circ} \mathrm{C} .\end{array}$ & $\begin{array}{l}\text { CONTF } \\
\mathrm{K}^{(\mathrm{b})} \\
10^{2}\left(\mathrm{hr}^{-1}\right)\end{array}$ & $\begin{array}{l}\text { OL } \\
\text { Activa- } \\
\text { tion } \\
\text { Energy } \\
\text { (K/cal) }\end{array}$ & $\frac{\mathrm{K}}{\mathrm{K} 10^{2}\left(\mathrm{hr}^{-1}\right)}$ & $\begin{array}{c}\text { Activation } \\
\text { Energy }\end{array}$ \\
\hline \multirow[t]{3}{*}{$10 \%$} & $20^{\circ}$ & 0.48 & $\therefore$ & 0.74 & \\
\hline & $30^{\circ}$ & 1.58 & 17.59 & 2.72 & 16.81 \\
\hline & $40^{\circ}$ & 3.22 & & 4.60 & \\
\hline \multirow[t]{3}{*}{$30 \%$} & 200 & 0.53 & & 0.94 & \\
\hline & $30^{\circ}$ & 1.86 & 19.19 & 3.13 & 15.71 \\
\hline & $40^{\circ}$ & 4.60 & & 5.52 & \\
\hline \multirow[t]{3}{*}{$50 \%$} & $20^{\circ}$ & 0.76 & & 1.01 & \\
\hline & $30^{\circ}$ & 2.07 & 19.19 & 4. 14 & 17.55 \\
\hline & $40^{\circ}$ & 5.98 & & 6.67 & \\
\hline \multirow[t]{3}{*}{$70 \%$} & $20^{\circ}$ & 1.40 & & 1.75 & \\
\hline & $30^{\circ}$ & 3.91 & 16.26 & 5.52 & 15.57 \\
\hline & $40^{\circ}$ & 8.28 & & 9.30 & \\
\hline
\end{tabular}

(a) All runs contained $10 \%$ concentration of buffer.

(b) Each $\mathrm{K}$ rate is the average of at least two runs.

(c) The Activation Energy is calculated from the average $K$ rates. 


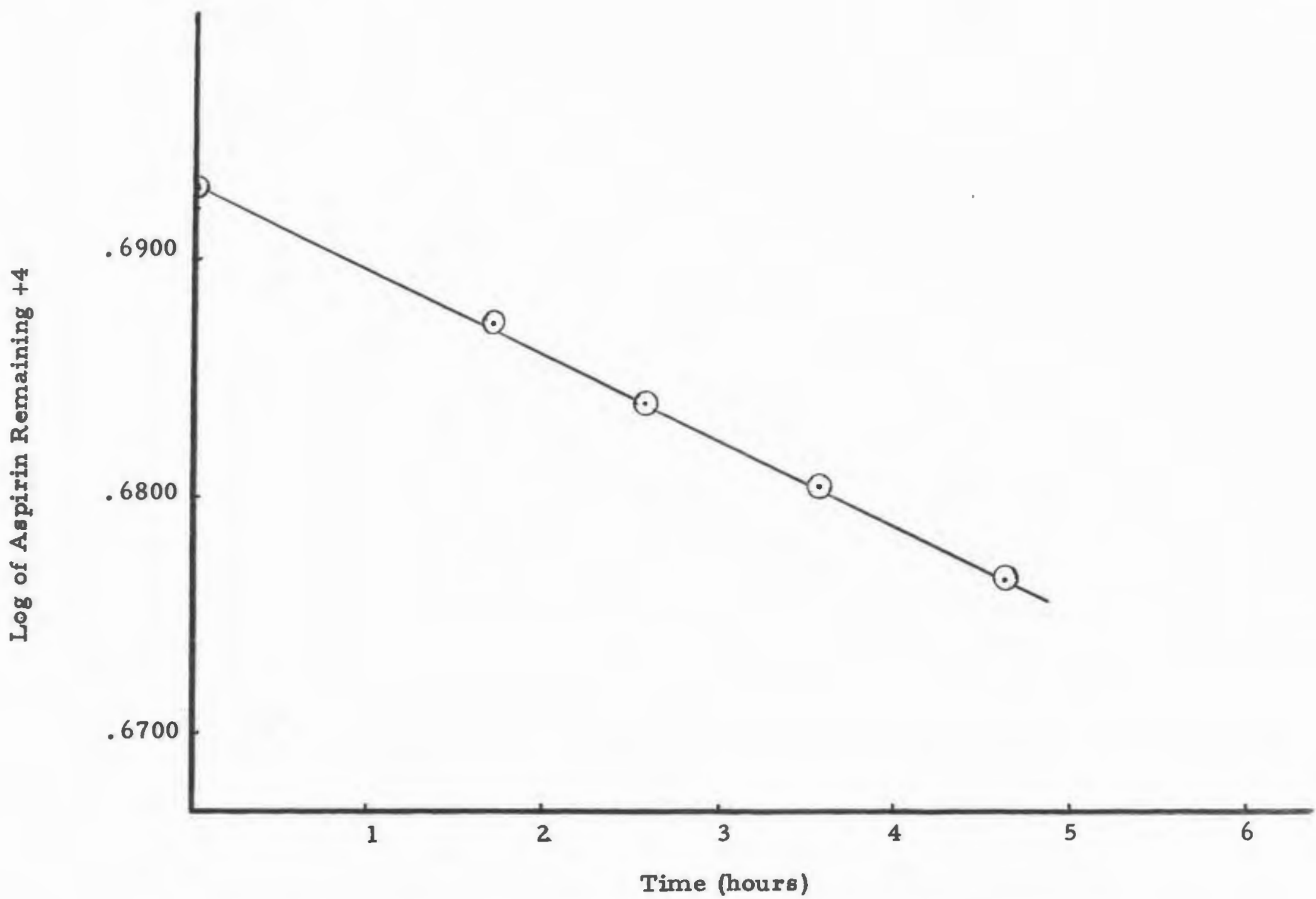

Figure 5. Pвeudo First Order Degradation of Aspirin in 1\% Diethyl Ether at $20^{\circ} \mathrm{C}$. Exposed to Ultrasound. 
TABLE II

THE EFFECT OF ULTRASONIC ENERGY ON THE

DEGRADATION OF APSIRIN IN SOLUTIONS

OF DIETHYL ETHER

\begin{tabular}{|c|c|c|c|c|c|}
\hline \multirow{2}{*}{$\begin{array}{l}\text { Percent } \\
\text { Concen- } \\
\text { tration } \\
\text { Diethyl } \\
\text { Ether }\end{array}$} & \multirow[b]{2}{*}{$\begin{array}{l}\text { Temper- } \\
\text { ature } \\
{ }^{\circ} \mathrm{C} \text {. }\end{array}$} & \multicolumn{2}{|c|}{ CONTROL } & \multicolumn{2}{|c|}{ ULTRASOUND } \\
\hline & & $\begin{array}{l}\mathrm{K}^{(\mathrm{b})} \\
\times 10^{2}(\mathrm{hr}-1)\end{array}$ & $\begin{array}{l}\text { tion } \\
\text { Energy } \\
\text { (K/cal) }\end{array}$ & $\begin{array}{l}\mathrm{K} \\
\mathrm{x} 10^{2}\left(\mathrm{hr}^{-1}\right)\end{array}$ & $\begin{array}{l}\text { Activa- } \\
\text { tion } \\
\text { Energy }\end{array}$ \\
\hline \multirow[t]{3}{*}{$1 \%$} & $20^{\circ}$ & 0.51 & & 0.99 & \\
\hline & $25^{\circ}$ & 0.68 & 18.90 & 1.20 & 14.93 \\
\hline & $30^{\circ}$ & 1.25 & & 1.90 & \\
\hline \multirow[t]{3}{*}{$3 \%$} & $20^{\circ}$ & 0.48 & & 0.74 & \\
\hline & $25^{\circ}$ & 1.00 & 19.60 & 1.35 & 18.12 \\
\hline & $30^{\circ}$ & 1.37 & & 1.89 & \\
\hline \multirow[t]{3}{*}{$5 \%$} & $20^{\circ}$ & 0.37 & & 0.60 & \\
\hline & $25^{\circ}$ & 0.77 & 19.72 & 1.13 & 17.6 \\
\hline & $30^{\circ}$ & 1.30 & & 1.65 & \\
\hline
\end{tabular}

(a) All runs contained 10\% concentration of buffer.

(b) Each $\mathrm{K}$ rate is the average of at least two runs.

(c) The Activation Energy is calculated from the average $\mathrm{K}$ rate. 


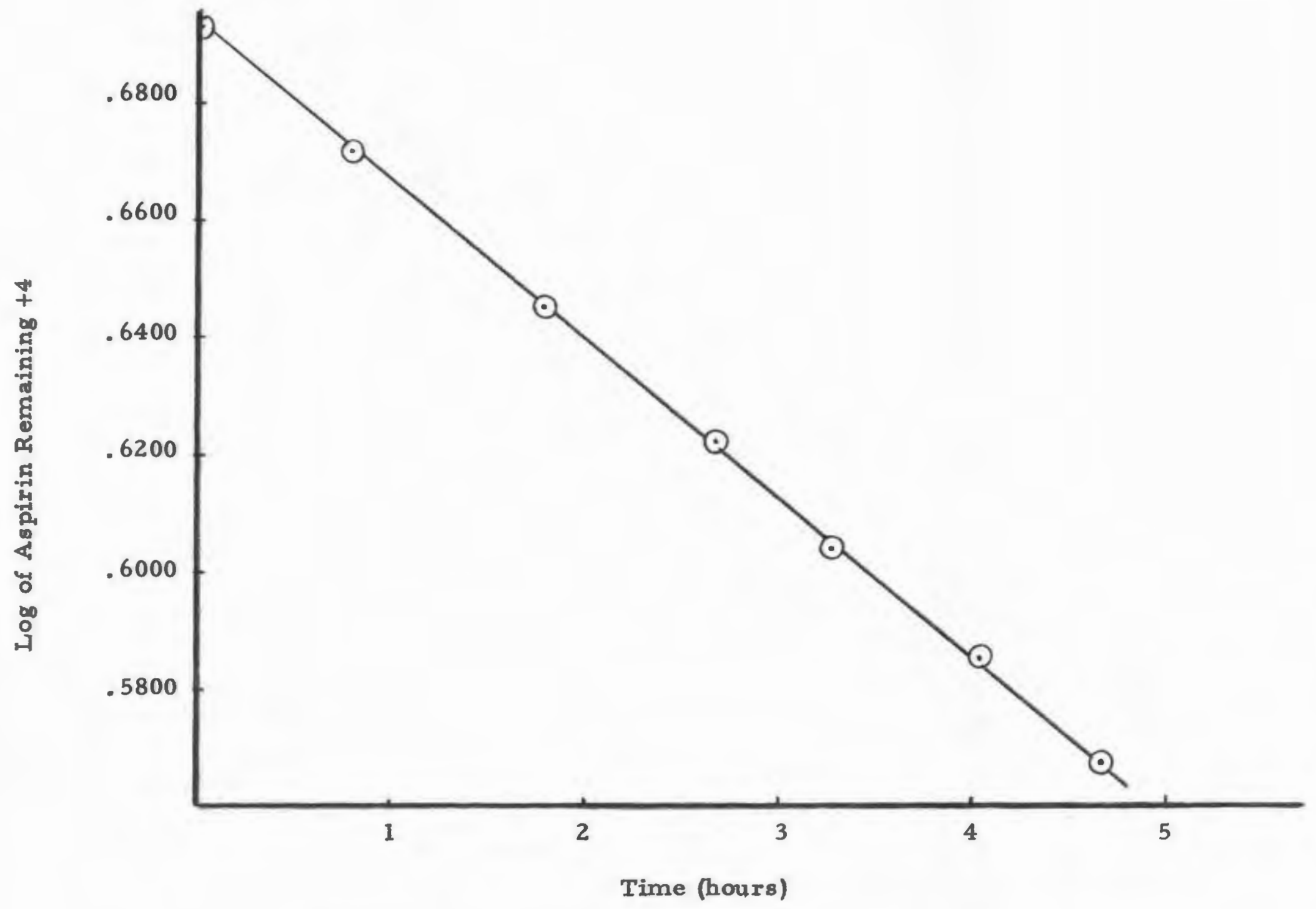

Figure 6. Pseudo First Order Degradation of Aspirin in 5\% Diethylene Glycol at $20^{\circ} \mathrm{C}$. Exposed to Ultrasound. 
TABLE III

THE EFFECT OF ULTRASONIC ENERGY ON THE

DEGRADATION OF ASPIRIN IN SOLUTIONS

OF DIETHY LENE GLYCOL

\begin{tabular}{|c|c|c|c|c|c|}
\hline $\begin{array}{l}\text { Percent (a) } \\
\text { Concen- } \\
\text { tration } \\
\text { Diethylene } \\
\text { Glycol }\end{array}$ & $\begin{array}{l}\text { Temper- } \\
\text { ature } \\
{ }^{\circ} \mathrm{C} \text {. }\end{array}$ & $\begin{array}{l}K \quad(b) \\
\times 10^{2}\left(h r^{-1}\right)\end{array}$ & $\begin{array}{l}\text { OL } \\
\text { Activa- (c) } \\
\text { tion } \\
\text { Energy } \\
\text { (K/cal) }\end{array}$ & $\begin{array}{l}\mathrm{K} \\
\times 10^{2}\left(\mathrm{hr}^{-1}\right)\end{array}$ & $\begin{array}{l}\text { Activa- } \\
\text { tion } \\
\text { Energy }\end{array}$ \\
\hline \multirow[t]{3}{*}{$5 \%$} & $20^{\circ}$ & 0.58 & & 4.60 & \\
\hline & $30^{\circ}$ & 1.73 & 16.80 & 5.06 & 3.66 \\
\hline & $40^{\circ}$ & 3.54 & & 7.65 & \\
\hline \multirow[t]{3}{*}{$10 \%$} & $20^{\circ}$ & $0.68^{\circ}$ & & 2. 99 & \\
\hline & $30^{\circ}$ & 1.62 & 16.40 & 5.02 & 7.57 \\
\hline & $40^{\circ}$ & 3.75 & & 6.72 & \\
\hline \multirow[t]{3}{*}{$30 \%$} & $20^{\circ}$ & 0.92 & & 2. 12 & \\
\hline & $30^{\circ}$ & 2.53 & 17.00 & 4.60 & 13.10 \\
\hline & $40^{\circ}$ & 5.82 & & 8.05 & \\
\hline \multirow[t]{3}{*}{$50 \%$} & $20^{\circ}$ & 1.24 & & 1.60 & \\
\hline & $30^{\circ}$ & 3.32 & 18.79 & 5.00 & 17.63 \\
\hline & $40^{\circ}$ & 8.80 & & 11.50 & \\
\hline
\end{tabular}

(a) All runs contained $10 \%$ concentration of buffer.

(b) Each $\mathrm{K}$ rate is the average of at least two runs.

(c) The Activation Energy is calculated from the average $\mathrm{K}$ rates. 
That portion of the energy causing degradation of a system which is contributed by ultrasound can be affected by the viscosity of the solvent medium. Figure 7 and Table IV illustrate the effect of change in viscosity on the rate of degradation. Laidler in his book on Chemical Kinetics (17) states, "The reaction of two molecules in solution can be thought of as occurring in three well defined stages: (1) diffusion of the molecules to each other, (2) the actual chemical transformation and (3) the diffusion of the products away from each other." He later stated that diffusion is not the rate determining step in a reaction and that the viscosity of a solvent system does not affect the chemical reaction rate. The fact that the effect of viscosity on a chemical degradation rate in the absence of ultrasound is negligible can be seen in Figure 7. Although the degradation rate of the control increases because of increasing temperature, the slope remains positive throughout each temperature range. The slope of the ultrasonically energized degradation changes from a minus slope at $20^{\circ} \mathrm{C}$. to a positive slope at $40^{\circ} \mathrm{C}$. At $20^{\circ} \mathrm{C}$. the viscosity of the diethylene glycol system changes from 1.95.centipoises at 5\% to 10.45 centipoises at $50 \%$. The increase in viscosity causes a distinct reduction in the degradation rate and may be attributed to decreased effectiveness of ultrasonic vibration. As the temperature increases, the difference in viscosity between $5 \%$ and $50 \%$ samples becomes less and the slope of the ultrasonic degradation approaches that of the control. In the ethanol and diethyl ether solvent systems, there is 


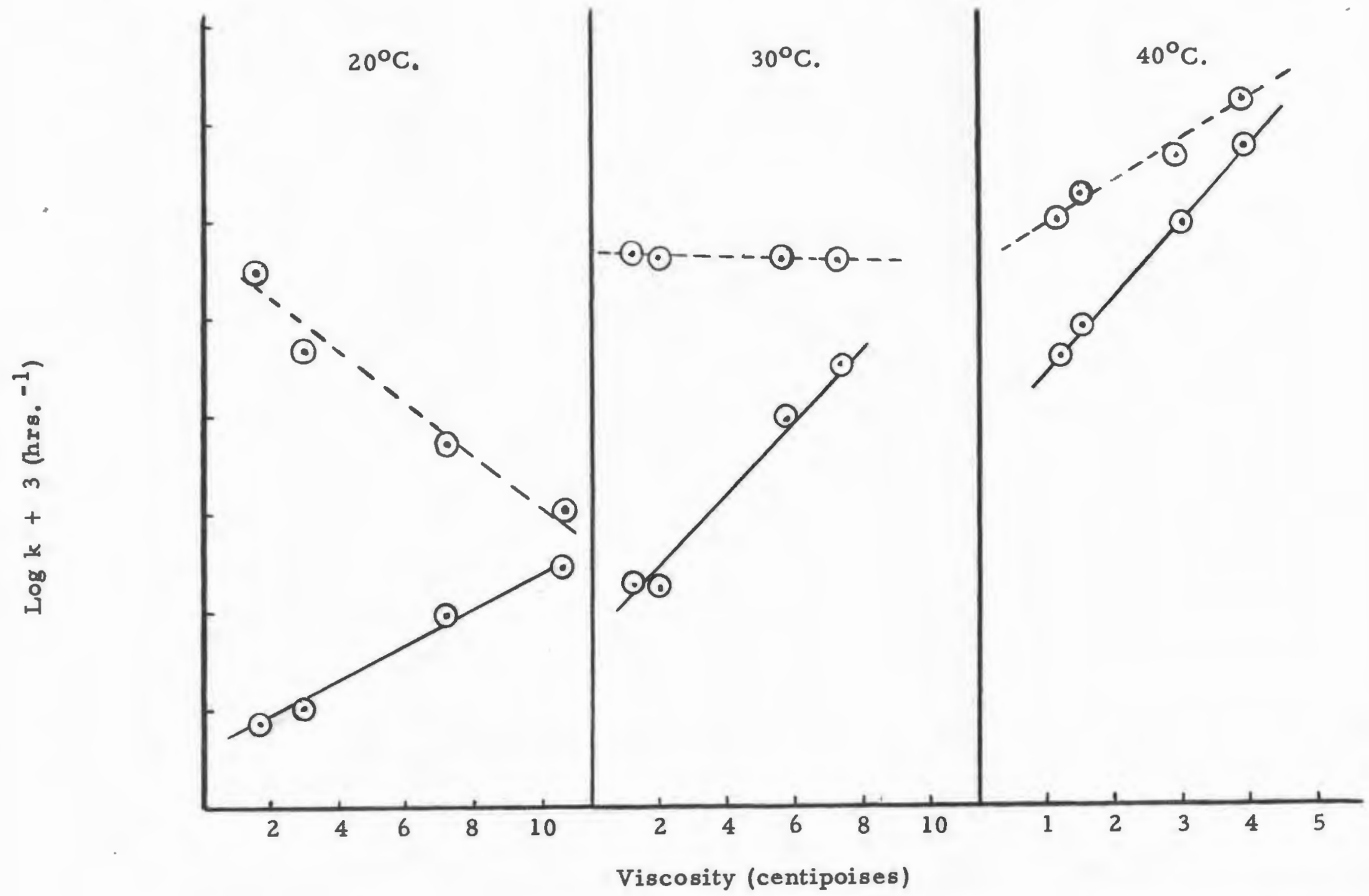

Figure 7. Comparison of Viscosity with the Log of the Rate of Degradation of Aspirin for 5\%, 10\%,30\%, 50\% Ethylene Glycol in Water at $20^{\circ}, 30^{\circ}, 40^{\circ} \mathrm{C}$. (- Without Ultrasound, ... With Ultrasound) 
TABLE IV

THE EFFECT OF VISCOSITY AND ULTRASONIC ENERGY ON THE DEGRADATION OF ASPIRIN IN SOLUTIONS

OF ETHYLENE GLYCOL

\begin{tabular}{|c|c|c|c|c|}
\hline $\begin{array}{l}\text { Percent } \\
\text { Ethylene } \\
\text { Glycol }\end{array}$ & $\begin{array}{c}\text { Temperature } \\
{ }^{\circ} \mathrm{C} .\end{array}$ & $\begin{array}{l}\text { Viscosity } \\
\text { (cps.) }\end{array}$ & $\begin{array}{l}\text { Control } \\
\mathrm{K} \\
\times 10^{2}\left(\mathrm{hr}^{-1}\right)\end{array}$ & $\begin{array}{l}\text { Ultrasound } \\
\mathrm{K} \\
\times 10^{2}\left(\mathrm{hr}^{-1}\right)\end{array}$ \\
\hline $5 \%$ & $\begin{array}{l}20^{\circ} \\
30^{\circ} \\
40^{\circ}\end{array}$ & $\begin{array}{l}1.950 \\
1.438 \\
1.103\end{array}$ & $\begin{array}{l}0.58 \\
1.73 \\
3.54\end{array}$ & $\begin{array}{l}4.60 \\
5.06 \\
7.65\end{array}$ \\
\hline $10 \%$ & $\begin{array}{l}20^{\circ} \\
30^{\circ} \\
40^{\circ}\end{array}$ & $\begin{array}{l}2.890 \\
2.086 \\
1.525\end{array}$ & $\begin{array}{l}0.68 \\
1.62 \\
3.75\end{array}$ & $\begin{array}{l}2.99 \\
5.02 \\
6.72\end{array}$ \\
\hline $30 \%$ & $\begin{array}{l}20^{\circ} \\
30^{\circ} \\
40^{\circ}\end{array}$ & $\begin{array}{l}6.670 \\
4.678 \\
3.215\end{array}$ & $\begin{array}{l}0.92 \\
2.53 \\
5.82\end{array}$ & $\begin{array}{l}2.12 \\
4.60 \\
8.05\end{array}$ \\
\hline $50 \%$ & $\begin{array}{l}20^{\circ} \\
30^{\circ} \\
40^{\circ}\end{array}$ & $\begin{array}{r}10.450 \\
7.270 \\
4.905\end{array}$ & $\begin{array}{l}1.24 \\
3.32 \\
8.80\end{array}$ & $\begin{array}{r}1.60 \\
5.00 \\
11.50\end{array}$ \\
\hline
\end{tabular}

(a) Viscosity taken from literature values (16). 
not sufficient differences in viscosity to produce this effect. Since the differences in viscosity in these two systems are very small, the slope of the ultrasonically effected degradation approaches that of the control throughout the temperature range. 


\section{CONCLUSIONS}

1. The application of ultrasonic energy to a system undergoing degradation will cause an increase in kinetic rate in ethanol-water, diethyl ether-water, and diethylene glycol water systems.

2. The lowering of the heat of activation is caused by the mechanical vibrations applied to the degrading system of ultrasonic energy.

3. The ultrasonic vibration increases the effect that the movement of the molecules toward each other and the movement of the products away from each other have on the overall rate.

4. As the concentration ratio is increased in a diethylene glycol-water system, the subsequent increase in viscosity reduces the effect on the movement of molecules caused by ultrasonic vibration. 


\section{REFERENCES}

1. Mark, H., J. Am. Acoust. Soc., 16, 183-7 (1945).

2. Prudhomme, R. O., and Grabar, P., Bull. Soc. Chim. Biol., 29, $122-130$ (1947).

3. Weissler, A., et al. , J. Applied Phys., 18, 434-8 (1947).

4. Gerraughty, R. J., and Jannke, P. J., J. Am. Pharm. Assoc. Sci. Ed., 49, 350 (1960).

5. Weissler, A., Cooper, H. W., and Snyder, S., J. Am. Chem. Soc. , 72, 1769-75 (1950).

6. Renaud, I., and Renaud, P., J. Chem. Phys., 49, 644 (1952).

7. Fenn, G. D., and Belcastro, P. F., J. Am. Pharm. Assoc. Sci. Ed., 49, 102-5 (1960).

8. Thompson, D., Vilbrandt, F. C., and Gray, W. C., J. Acoust. Soc. Amer., 27, 556-63 (1955).

9. Mario, E. A., The Effect of Ultrasound on the Hydrolysis of Aspirin, Masters Thesis, University of Rhode Island (1963).

10. Edwards, L. J., Trans Faraday Soc., 46, 723-735 (1950).

11. Ibid., 4ㄴ, 696-9 (1952).

12. Garrett, E., I. Am. Chem. Soc., 79, $3401-4$ (1957).

13. Garrett, E., J. Org. Chem. , 26, 3660-5 (1960).

14. Mario, E. A. and Gerraughty, R. J., J. Pharm. Sci., 54, 321 (1965). 
15. Ibid., p. 321 .

16. Weast, R. C. and Selby, S. M. , Handbook of Chemistry and Physics, 47th edition. Cleveland: The Chemical Rubber Company, 1966.

17. Laidler, K. J., Chemical Kinetics, 2nd edition. New York: McGraw-Hill Book Company, 1965. 
LIST OF TABLES

TABLE

PAGE

I. The Effect of Ultrasonic Energy on the Degradation of Aspirin in Solutions of Ethanol . . . . . . . . . . . . .

II. The Effect of Ultrasonic Energy on the Degradation of Aspirin in Solutions of Diethyl Ether . . . . . . . . . . . .

III. The Effect of Ultrasonic Energy on the Degradation of Aspirin in Solutions of Diethylene Glycol . . . . . . . . . .

IV. The Effect of Viscosity and Ultrasonic Energy on the Degradation of Aspirin in Solutions of Ethylene Glycol . . . . . . . . . . 